\title{
Description and Use of a Geographic- Information-System-Based Water Information Management and Analysis System (WIMAS)
}

\section{By KYLE E. JURACEK}

U.S. Geological Survey

Open-File Report 94-46

Prepared in cooperation with the Kansas State Board of Agriculture, Division of Water Resources

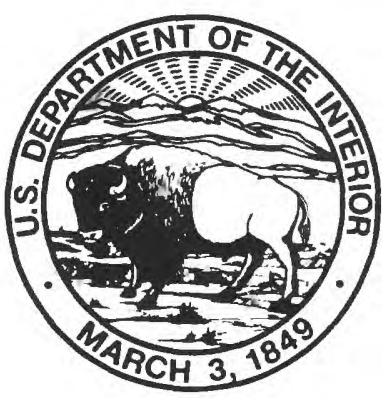




\title{
U.S. DEPARTMENT OF THE INTERIOR \\ BRUCE BABBITT, Secretary
}

\author{
U.S. GEOLOGICAL SURVEY \\ GORDON P. EATON, Director
}

For additional information write to:

Copies of this report can be purchased from:

U.S. Geological Survey

District Chief

Earth Science Information Center

U.S. Geological Survey

Open-File Reports Section

Water Resources Division

Box 25286, MS 517

4821 Quail Crest Place

Denver Federal Center

Lawrence, Kansas 66049-3839

Denver, Colorado 80225 


\section{CONTENTS}

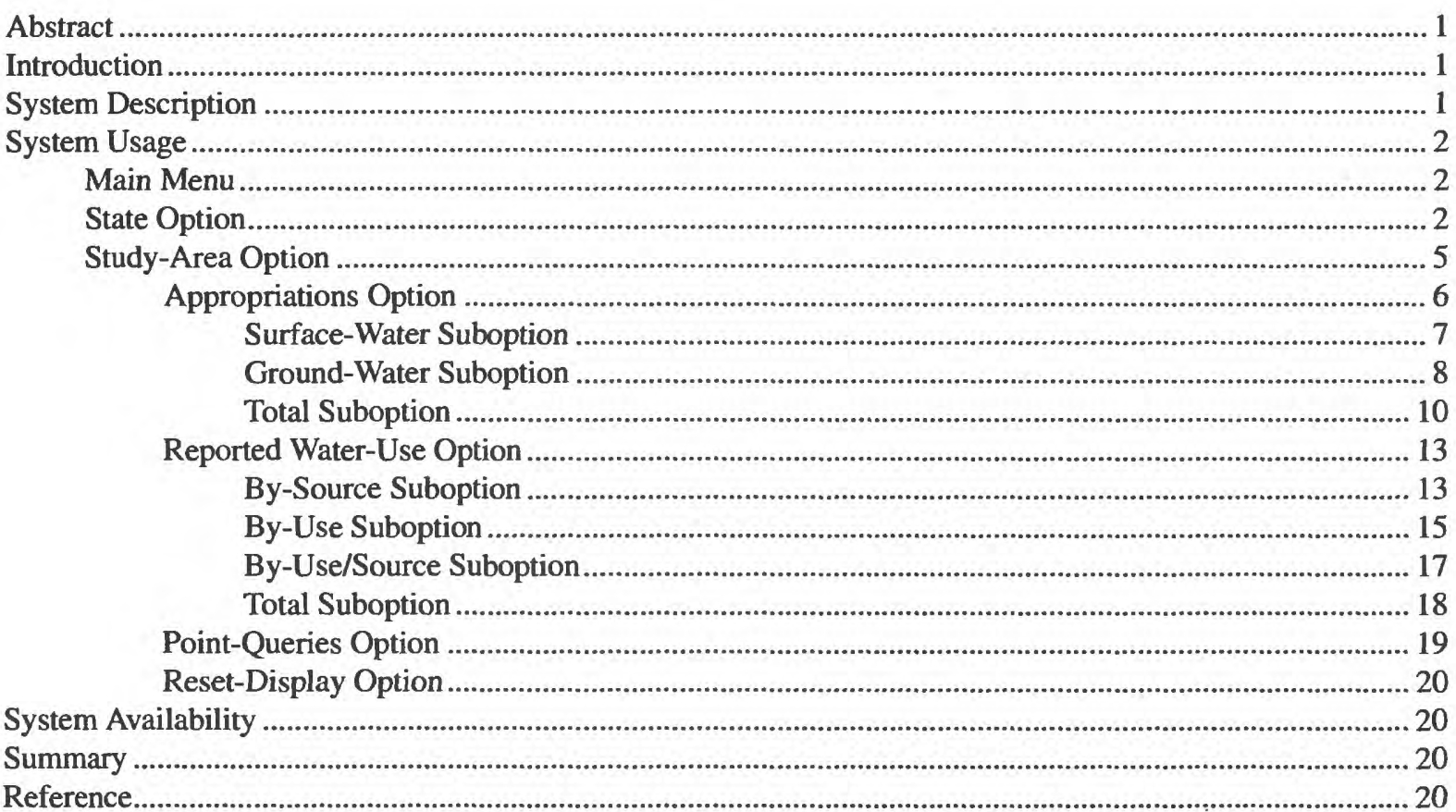

\section{TABLES}

1. Statewide digital maps used by the Water Information Management and Analysis System (WIMAS)

2. Hypothetical example of a surface-water-appropriations listing.............................................................. 7

3. File-naming suffixes used by the Water Information Management and Analysis System

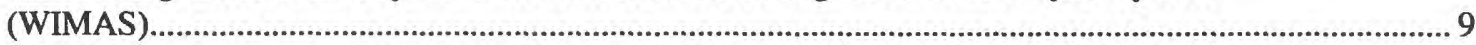

4. Basin names and associated codes of the Kansas State Board of Agriculture, Division of Water

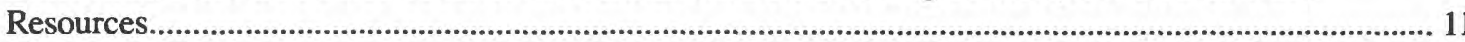

5. Hypothetical example of an appropriations listing that includes water-use correspondent

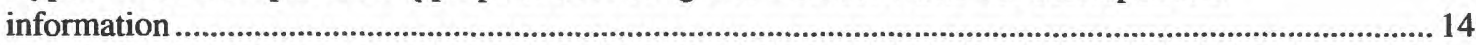

6. Hypothetical example of a surface-water-diversions listing ................................................................. 14

7. Water-use categories and associated abbreviations of the Kansas State Board of Agriculture,

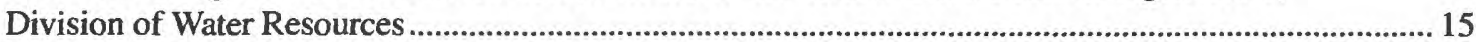

8. Hypothetical example of a diversions listing that includes water-use correspondent information............. 19 
CONVERSION FACTORS

\begin{tabular}{rll}
\hline Multiply & By & To obtain \\
\hline foot & 0.3048 & meter \\
mile & 1.609 & kilometer \\
square mile & 2.590 & square kilometer \\
gallon & 3.785 & liter \\
acre-foot & 1,233 & cubic meter \\
\hline
\end{tabular}




\title{
Description and Use of a Geographic-Information- System-Based Water Information Management and Analysis System (WIMAS)
}

\author{
By Kyle E. Juracek
}

\section{Abstract}

The management and analysis of water resources are challenging tasks due to their complexity and data-intensive nature. In Kansas, a primary source of hydrologic information is the Kansas State Board of Agriculture's Division of Water Resources, which maintains extensive digital data bases that contain information on water appropriations and water use by point of diversion. To date, optimal use of the data bases by the Division of Water Resources and other entities within the State has been inhibited by the lack of an effective means to access, analyze, and display the information. To expedite and improve the use of the data bases for water-resources management and research, geographicinformation-system technology was used to develop a user-support tool referred to as the Water Information Management and Analysis System (WIMAS) ${ }^{1}$. WIMAS has the capability of summarizing water-appropriations and water-use information by user-defined geographic area, source of water, and type of water use.

\section{INTRODUCTION}

To improve accessibility and enhance the use of the Kansas State Board of Agriculture, Division of Water Resources' water-appropriations and water-use data bases, the Division of Water

\footnotetext{
${ }^{1}$ Although this program has been used by the U.S. Geological Survey, no warranty, expressed or implied, is made by the U.S. Geological Survey or the United States Government as to the accuracy and functioning of the program and related program material nor shall the fact of distribution constitute any such warranty, and no responsibility is assumed by the U.S. Geological Survey in connection therewith.
}

Resources, in cooperation with the U.S. Geological Survey, used geographic-information-system (GIS) technology to develop a user-support tool referred to as the Water Information Management and Analysis System (WIMAS). WIMAS is intended to help meet the water-appropriations and wateruse data needs of various entities (for example, State and Federal agencies, universities) in Kansas. Specifically, WIMAS enables users to summarize the Division of Water Resource's water-appropriations and water-use information by user-defined geographic area, source of water, and type of water use. Additionally, WIMAS provides capabilities that are particular to the needs of the Division of Water Resources. This report describes the generalpurpose capabilities of WIMAS and focuses on system usage.

\section{SYSTEM DESCRIPTION}

WIMAS was developed on a Data General $\mathrm{AViiON}^{2}$ workstation that operates in a UNIX and $\mathrm{X}$-Windows environment. The system was developed using the ARC/INFO (version 6.1) GIS software package (Environmental Systems Research Institute, Inc., 1992). Use of the ARC/ INFO software requires a license.

The WIMAS software was programmed in the ARC Macro Language (AML) (Environmental Systems Research Institute, Inc., 1992). User interaction with WIMAS is enabled by graphics-display and text windows, as well as several menus that appear as necessary. Onscreen messages provide instructions, explanations, and results. The development of WIMAS involved an integration of digital data bases independently maintained by several State and Federal agencies.

\footnotetext{
${ }^{2}$ The use of brand names in this report is for identification purposes only and does not constitute endorsement by the U.S. Geological Survey.
} 


\section{SYSTEM USAGE}

WIMAS requires that the user be running ARC/INFO (version 6.1) in a UNIX and $\mathrm{X}$-Windows environment and that the "ArC:" prompting message is displayed. To begin a WIMAS session, the following command is typed:

\section{Arc: \&r wimas_2}

In this report, italicized and bold lettering is used to distinguish between the messages displayed on the terminal screen and the information typed by the user. In the example above, "ArC:" is displayed on the terminal screen (that is, in a text window), and "\&r wimas_2" is typed by the user. Throughout a WIMAS session, all instructions, explanations, and results are displayed in the text window where the session was initiated. User response to system prompts requires that the text window be "active." A window is active whenever the screen cursor is placed within it. Previous information in the text window can be reviewed by using the cursor to click and drag on the scroll bar located on the left side of the window. If the user needs to "break out" of the session (for example, if normal control of the program is lost), this can be accomplished by simultaneously pressing the "control" and "C" keys on the keyboard.

\section{Main Menu}

After the display of introductory information, the following prompt appears in the text window:

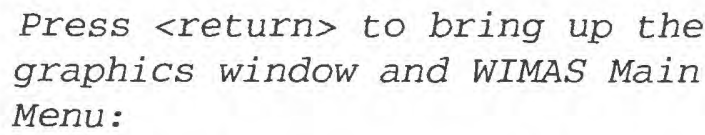

After the user responds, the Arcplot graphics window is displayed on the terminal screen. The location and size of the graphics window may be changed at any time during a WIMAS session. However, changing the size of the graphics window will result in the deletion of the current graphics display. After the graphics window appears, messages are displayed that document the year of the water-use data and date of retrieval of all Division of Water Resources' information that is available for analysis (WIMAS uses a downloaded "snapshot" of the Division of Water
Resources' data bases). Finally, the WIMAS main menu appears as follows:

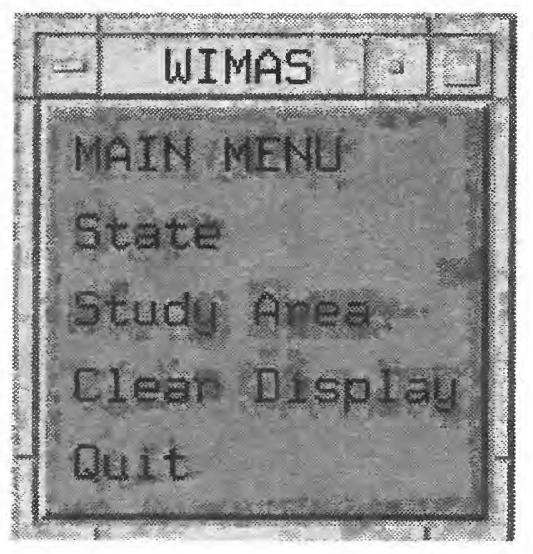

A menu option is selected using the cursor to point to and click on the desired choice. A subsequent menu selection may not be made until the cursor (while located on the menu) changes from the "clock" symbol back to its "original" symbol. The "clock" symbol indicates that the system is either processing the current request or waiting for user input from the keyboard or cursor. The "Clear Display" option allows the user to clear the graphics-window display at any time. Once the display has been cleared, control is returned to the main menu. The "Quit" option allows the user to exit WIMAS and return to the UNIX prompt. The location of a menu on the terminal screen can be changed at any time during a WIMAS session by using the cursor to click and drag on the title bar at the top of the menu (in the main menu the title bar is labeled "WIMAS").

\section{State Option}

The "State" option lists several statewide digital maps (that is, ARC/INFO coverages) that can be displayed singly or in combination. The intent of the "State" option is to provide the user a means of viewing various types of spatial information in order to identify and (or) to better understand a particular area of interest. The digital maps used by WIMAS (not all of which are available for display via the "State" option) are described in table 1. Digital maps are selected from the following submenu that is displayed automatically when the "State" option is chosen: 
Table 1. Statewide digital maps used by the Water Information Management and Analysis System (WIMAS)

\begin{tabular}{|c|c|}
\hline Description & Source and scale \\
\hline Aquifer boundaries & U.S. Geological Survey $(1: 2,000,000)$ \\
\hline City boundaries & U.S. Geological Survey $(1: 100,000)$ \\
\hline Contaminated sites & $\begin{array}{l}\text { Kansas Department of Health and Environment } \\
(1: 24,000)\end{array}$ \\
\hline County boundaries & Kansas Geological Survey $(1: 24,000)$ \\
\hline $\begin{array}{l}\text { Division of Water Resources' } \\
\text { basin boundaries }\end{array}$ & Division of Water Resources $(1: 250,000)$ \\
\hline $\begin{array}{l}\text { Division of Water Resources' } \\
\text { groundwater-management- } \\
\text { district boundaries }\end{array}$ & Division of Water Resources $(1: 100,000)$ \\
\hline $\begin{array}{l}\text { Division of Water Resources' } \\
\text { intensive groundwater-use } \\
\text { (or special water-quality) } \\
\text { control-area boundaries }\end{array}$ & Division of Water Resources $(1: 100,000)$ \\
\hline Feedlot point locations & $\begin{array}{l}\text { Kansas Department of Health and Environment } \\
\text { (none) }\end{array}$ \\
\hline Points of water diversion & Division of Water Resources (none) \\
\hline Populated places & U.S. Geological Survey $(1: 24,000)$ \\
\hline Railroad network & U.S. Geological Survey $(1: 100,000)$ \\
\hline River reaches & $\begin{array}{l}\text { U.S. Environmental Protection Agency } \\
(1: 500,000)\end{array}$ \\
\hline Road network & U.S. Geological Survey $(1: 100,000)$ \\
\hline Rural Water District boundaries & Kansas Water Office $(1: 100,000)$ \\
\hline Section corners & Kansas Geological Survey $(1: 24,000)$ \\
\hline State boundary & Kansas Geological Survey $(1: 24,000)$ \\
\hline Stream drainages & U.S. Geological Survey $(1: 2,000,000)$ \\
\hline Township boundaries & Kansas Geological Survey $(1: 24,000)$ \\
\hline $\begin{array}{l}\text { U.S. Geological Survey basin } \\
\text { boundaries }\end{array}$ & U.S. Geological Survey $(1: 500,000)$ \\
\hline
\end{tabular}




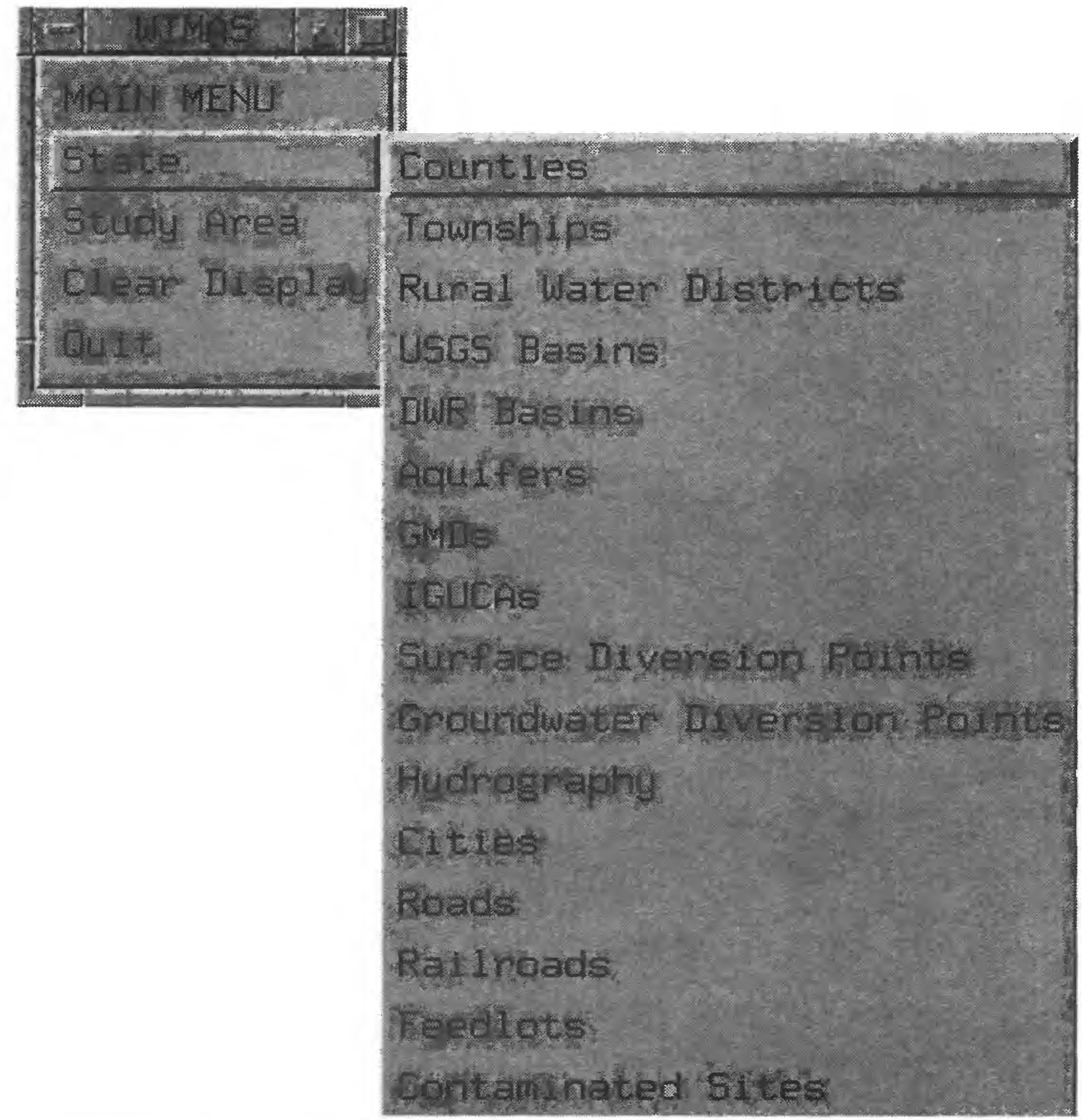

"USGS Basins" in the "State" submenu are drainage basins (that is, hydrologic units) delineated by the U.S. Geological Survey. " $D W R$ Basins" in the "State" submenu are drainage basins delineated by the Division of Water

Resources. "GMDS" are groundwater management districts established under Kansas law. "I GUCAs" are intensive groundwater-use (or special waterquality) control areas established by the Division of Water Resources.

Selecting a suboption from the "State" submenu results in the display of a specific digital map. (Note: Only one digital map can be selected at a time.) Many of the digital maps include optional attribute (that is, textual) information. For example, subsequent to the display of the

"Counties" digital map, the following prompt is displayed:

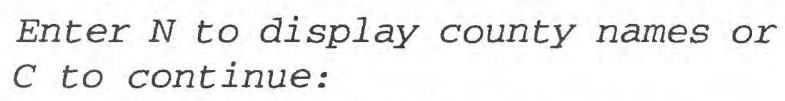

Typing "N" or " $n$ " will display the county names and then return the user to the main menu. Typing " $C$ " or " $C$ " returns the user to the main menu. Additional digital maps may be selected and displayed by repeatedly selecting the "State" option and choosing one of the submenu options. This enables the user to overlay multiple digital maps. 


\section{Study-Area Option}

The "Study Area" option in the main menu provides access to the water-appropriations and water-use analytical applications. Selecting the "Study Area" option results in the automatic display of the following submenu:
The pulldown menu is organized alphabetically. For example, the " $A-C$ " option lists all counties with names that begin with $\mathrm{A}, \mathrm{B}$, or $\mathrm{C}$. A county is chosen by first selecting the alphabetical range that contains the first letter of the name of the desired county. Subsequently, a submenu is dis-

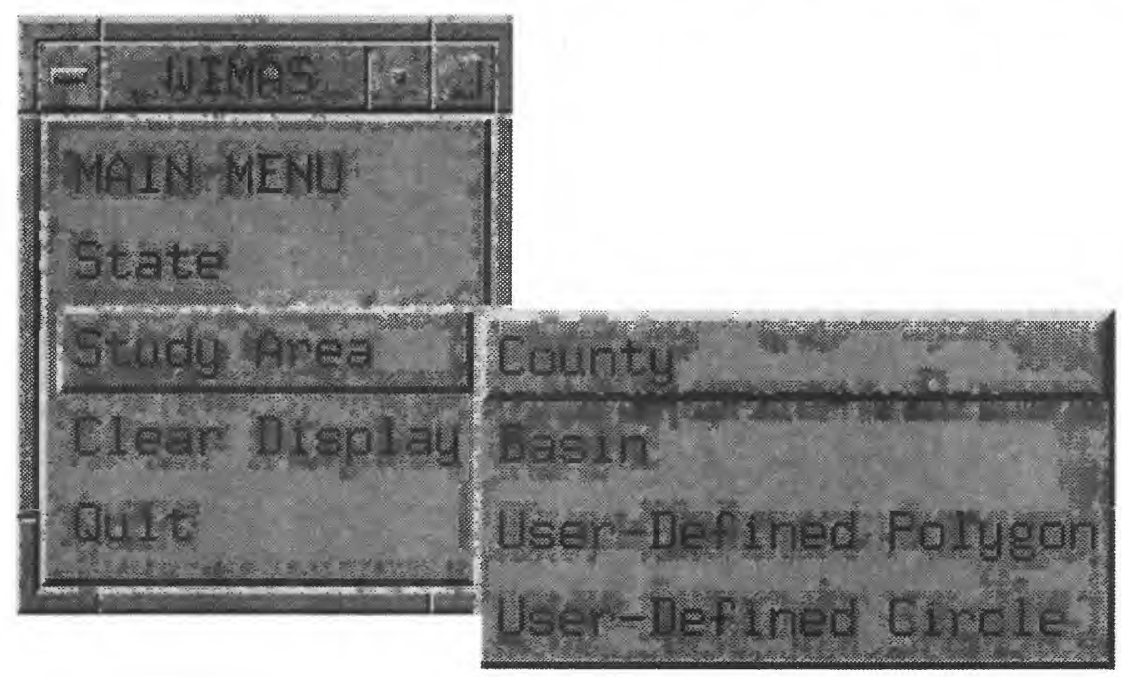

The "Study Area" submenu provides generalpurpose suboptions that allow the user to query available water-appropriations and water-use information by county, basin, user-defined polygon, and user-defined circle. Although the "User-Defined Polygon" and "UserDefined Circle" suboptions can accommodate areas of any size, graphical results are most effective for relatively small areas. Specifically, polygons less than 200 square miles and circles of radius less than 5 miles are ideal.

Once invoked, the "Study Area" suboptions prompt the user to specify the target area of interest. The "County" and "Bas in" suboptions provide an additional menu from which the user may select a county or basin. For example, in the "County" suboption, a pulldown menu (shown below) is invoked that includes all 105 counties in Kansas. played from which the user selects the individual county. The "QUIT" option in the pulldown menu returns the user to the main menu.

The "User-Defined Polygon" suboption allows the user to interactively define the target area. Initially, a map of Kansas is displayed in the graphics window to provide a frame of reference for the polygon specification. The map of Kansas includes county-boundary, county-name, and stream-drainage information. The user is prompted to zoom in on the target area by the following message:

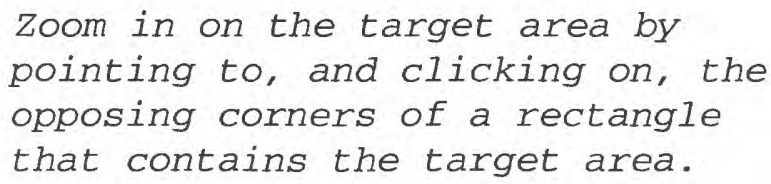

When the above message appears, the user moves the cursor into the graphics window and waits for the cross hairs to align with the cursor. Subse- 
quently, the user proceeds by pointing to and clicking on the opposing corners of the rectangle. Once defined, an enlarged view of the rectangular area is displayed in the graphics window, and the following message is displayed:

\section{Define the polygon (press 9 when complete).}

At this point, the user interactively defines the target area using the cursor to click on the nodes (corners) of the polygon that defines the boundary of the area. (Note: The polygon can be any shape or size required.) When complete, the polygon is closed by pressing the "9" key.

Likewise, in the "User-Defined Circle" suboption, the user interactively defines the target area. Initially, the user is given the choice of selecting either a county or a township to provide a frame of reference for a circle specification. The following prompt appears:

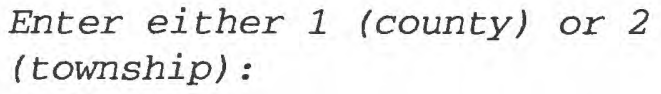

Typing " 1 " invokes a menu from which a county may be selected. Typing " 2 " results in the following prompt:

Enter the township number (e.g., $23 \mathrm{~s} 02 \mathrm{w})$ :

The user then enters the desired township number. Once identified, the selected county or township is displayed in the graphics window. The display includes points of diversion, stream drainages, township boundaries and numbers, GMD boundaries (if present), IGUCA boundaries (if present), and cities. The following prompt then is displayed:

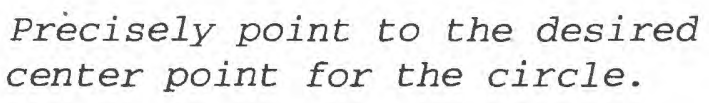

When this prompt appears, the user moves the cursor into the graphics window and waits for the cross hairs to align with the cursor. Subsequently, the user specifies the center point by pointing to and clicking on the desired location. The following prompt then appears:

Enter the desired circle radius (in miles):
At this point, the user enters the desired circle radius to complete the circle specification. (Note: The radius may be given as either an integer or a decimal number.)

Once selected or defined, the target area is displayed in the graphics window. For all target areas, the display includes points of diversion, stream drainages, cities, and if present, restricteduse areas (that is, GMDs and IGUCAs). The user then is given the choice of performing an analysis. In each of the four "Study Area" suboptions, the following prompt is displayed:

\section{Enter 1 for analysis menu or 2 to quit and return to the main menu:}

Typing "2" returns the user to the main menu. Typing " 1 " invokes the analysis menu that provides a standard set of capabilities that is identical for each of the four "Study Area" suboptions. For example, the "Bas in" analysis menu appears as follows:

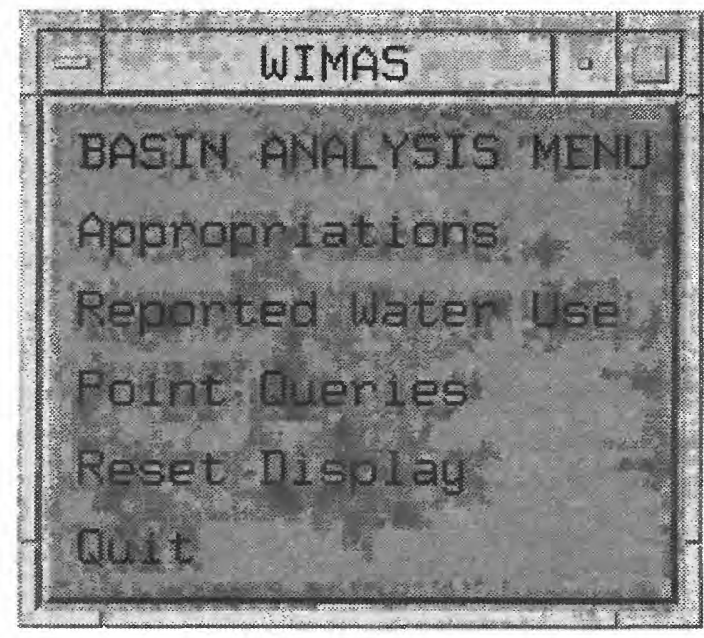

The "Quit" option in the analysis menus returns the user to the main menu. The other options are described below.

\section{Appropriations Option}

The "Appropriations" option in the analysis menus provides the following submenu: 


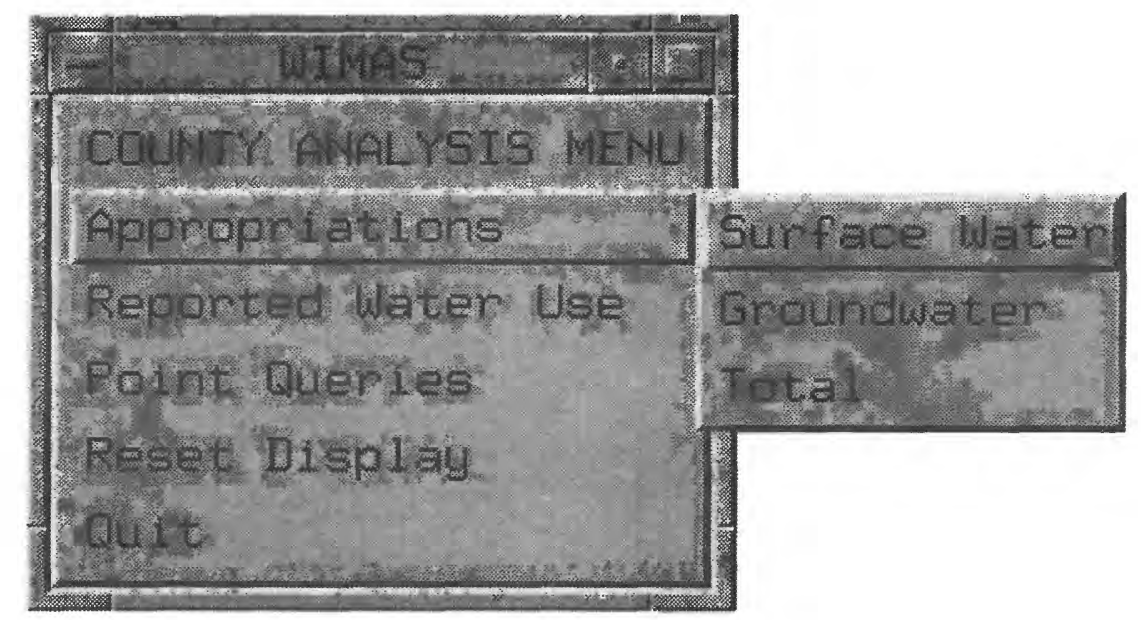

The "Appropriations" suboptions are described below.

\section{Surface-Water Suboption}

The "Surface Water" suboption in the "Appropriations" submenu summarizes surface-water appropriations within the target area. If no surface-water appropriations exist in the target area, WIMAS informs the user. For example, in a "County" analysis, the following messages are displayed:

There were no surface-water

appropriations in this county as of January 15, 1993.

Returning to the county menu...

The user is returned to the "County" analysis menu.

If there are surface-water appropriations in the target area, they are displayed in a unique color in the graphics window and accompanied by the following message:

Surface-water diversions are displayed in green.
WIMAS then automatically performs a summary analysis of the surface-water appropriations and displays the results. A hypothetical example of the results displayed for a "County" analysis is the following:

In Ellis County, 1,000 acre-feet of surface water were appropriated as of January 15, 1993.

The appropriations were distributed among 10 points of diversion.

The following prompt then is displayed:

Enter 1 to list the appropriations
or 2 to return to the menu (Note:
Hard copy requires that the
appropriations be listed):

Typing " 2 " returns the user to the analysis menu. Typing " 1 " results in the listing of all surface-water appropriations in the target area. A hypothetical example of the listing displayed is provided in table 2. The "FILE-ID" column lists the Division of Water Resources' file number (that is, the permit or water-right number). The "OVLP" column indicates whether or not an overlap exists. An asterisk

Table 2. Hypothetical example of a surface-water-appropriations listing

\begin{tabular}{cccccccc}
\hline FILE-ID & OVLP & TWP & RNG & SECT & DWR-ID & QUALIFIERS ACRE-FEET \\
\hline & & & & & & & \\
$\mathrm{A} 012345-67$ & $*$ & $10 \mathrm{~S}$ & $40 \mathrm{~W}$ & 15 & 01 & 25751460 & 500 \\
$\mathrm{~A} 076543-21$ & $*$ & $06 \mathrm{~S}$ & $38 \mathrm{~W}$ & 12 & 03 & SWNWSE & 250 \\
\hline
\end{tabular}


in the "OVLP" column indicates that the permit or water right overlaps with another permit or water right. The next four columns, "TWP," "RNG," "SECT," and "DWR-ID," list the township, range, section, and Division of Water Resources' sequential identification number, respectively. The "QUALIFIERS" column lists the qualifiers from the Division of Water Resources' data base that describe the location of the appropriation either in terms of the quarter system (for example, "SWNWSE" indicates that the appropriation is located in the southwest quarter of the northwest quarter of the southeast quarter of the section) or in feet north and west of the southeast corner of the section (for example, "25751460" indicates that the appropriation is located 2,575 feet north and 1,460 feet west of the southeast corner of the section). All feet-north and feet-west values are 4-digit numbers that are greater than or equal to zero and typically less than or equal to 5,280. Finally, in the "ACRE-FEET" column, the appropriated annual quantity (acre-feet) is listed. If a hard copy of the listing is desired, the appropriations must be listed. The appropriations that are listed are written to a file (in the user's workspace) that is available for hard-copy generation.

Following the list of surface-water appropriations, WIMAS displays a message that provides the user the name of the newly created file. An example of the message displayed in a "County" analysis is the following:

A file for hard-copy generation, entitled ellis.swa, has been created in your workspace. The file contains the above-listed surface-water appropriations.

The file name provides information about the file's contents. In this case, the prefix "ellis" informs the user that the file contains information about Ellis County, Kansas. The suffix "swa" is an abbreviation that indicates that the file contains information about surface-water appropriations. A listing of all the file-naming suffixes used in WIMAS is provided in table 3.

Finally, a message is displayed that indicates the end of the analysis. For example, in a "County" analysis, the following message appears:
To select another county, click on "Quit" in the county menu to return to the main menu.

At this point, the surface-water-appropriations analysis is concluded, and the user is returned to the analysis menu. Two choices are now available. First, the user may select another analysis option to be performed on the same target area. Second, the user may select the "Quit" option to return to the main menu to select a different target area or exit WIMAS.

\section{Ground-Water Suboption}

The "Ground-Water" suboption in the "Appropriations" submenu summarizes ground-water appropriations within the target area. If no ground-water appropriations exist in the target area, WIMAS informs the user. For example, in a "Bas in" analysis, the following messages are displayed:

There were no ground-water

appropriations in this basin as of January 15, 1993.

Returning to basin menu...

The user is returned to the "Basin" analysis menu.

If there are ground-water appropriations in the target area, they are displayed in a unique color in the graphics window and accompanied by the following message:

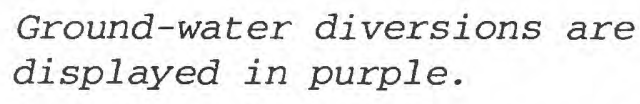

WIMAS then automatically performs a summary analysis of the ground-water appropriations and displays the results. A hypothetical example of the results displayed for a "Basin" analysis is the following:

In the Pawnee River Basin, 10,000 acre-feet of ground water were appropriated as of January 15, 1993.

The appropriations were distributed among 100 points of diversion.

The following prompt then is displayed: 
Table 3. File-naming suffixes used by the Water Information Management and Analysis System (WIMAS)

\begin{tabular}{|c|c|}
\hline Suffix & Explanation \\
\hline argwu & Artificial-recharge ground-water use \\
\hline arswu & Artificial-recharge surface-water use \\
\hline arwu & Artificial-recharge water use \\
\hline crgwu & Contamination-remediation ground-water use \\
\hline crswu & Contamination-remediation surface-water use \\
\hline crwu & Contamination-remediation water use \\
\hline dgwu & Domestic ground-water use \\
\hline dswu & Domestic surface-water use \\
\hline dwu & Domestic water use \\
\hline gwa & Ground-water appropriations \\
\hline gwu & Ground-water use \\
\hline hdgwu & Hydraulic-dredging ground-water use \\
\hline hdswu & Hydraulic-dredging surface-water use \\
\hline hdwu & Hydraulic-dredging water use \\
\hline ingwu & Industrial ground-water use \\
\hline inswu & Industrial surface-water use \\
\hline inwu & Industrial water use \\
\hline irgwu & Irrigation ground-water use \\
\hline irswu & Irrigation surface-water use \\
\hline irwu & Irrigation water use \\
\hline mgwu & Municipal ground-water use \\
\hline mswu & Municipal surface-water use \\
\hline mwu & Municipal water use \\
\hline rgwu & Recreation ground-water use \\
\hline rswu & Recreation surface-water use \\
\hline rwu & Recreation water use \\
\hline stgwu & Stockwatering ground-water use \\
\hline stswu & Stockwatering surface-water use \\
\hline stwu & Stockwatering water use \\
\hline swa & Surface-water appropriations \\
\hline swu & Surface-water use \\
\hline twa & Total water appropriations \\
\hline twu & Total water use \\
\hline wpgwu & Water-power ground-water use \\
\hline wpswu & Water-power surface-water use \\
\hline wpwu & Water-power water use \\
\hline
\end{tabular}


Enter 1 to 1 ist the appropriations or 2 to return to the menu (Note: Hard copy requires that the appropriations be 1 isted):

Typing " 2 " returns the user to the analysis menu. Typing " 1 " results in the listing of all ground-water appropriations in the target area. A hypothetical example of the listing displayed, as well as an explanation of the information listed, is provided in the preceding "Surface Water" section. If a hard copy of the listing is desired, the appropriations must be listed. The appropriations that are listed are written to a file (in the user's workspace) that is available for hard-copy generation.

Following the list of ground-water appropriations, WIMAS displays a message that provides the user the name of the newly created file. An example of the message displayed in a "Basin" analysis is the following:

\section{A file for hard-copy generation, entitled basin59. gwa, has been created in your workspace. The file contains the above-listed ground-water appropriations.}

The file name provides information about the file's contents. In this case, the prefix "basin59" informs the user that the file contains information about a specific basin (in this case, the Pawnee River Basin in Kansas). The suffix "gwa" is an abbreviation that indicates that the file contains information about ground-water appropriations. Table 4 lists the basin names and associated codes as identified by the Division of Water Resources.

Finally, a message is displayed that indicates the end of the analysis. For example, in a "Basin" analysis, the following message is displayed:

To select another basin, click on "Quit" in the basin menu to return to the main menu.

At this point, the ground-water-appropriations analysis is concluded, and the user is returned to the analysis menu. If desired, the user may select another analysis option to be performed on the same target area. Otherwise, the user may select the "Quit" option to return to the main menu to select another target area or exit WIMAS.

\section{Total Suboption}

The "Total" suboption in the "Appropriations" submenu collectively summarizes all water appropriations within the target area. WIMAS informs the user if no water appropriations exist in the target area. For example, in a "User-Defined CirCle" analysis, the following messages are displayed:

There were no appropriations in the circle as of January 15, 1993.

Returning to the circle menu...

The user is returned to the "CirCle" analysis menu.

If there are water appropriations in the target area, WIMAS automatically performs the summary analysis of all appropriations and displays the results. A hypothetical example of the results displayed for a "User-Defined Circle" analysis is the following:

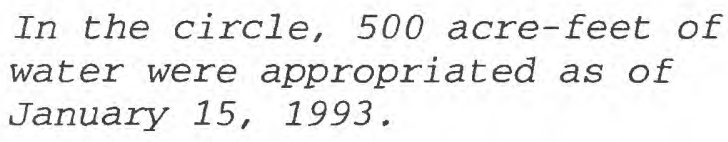

The appropriations were distributed among 7 points of diversion.

The following prompt then is displayed:

Enter 1 to list the appropriations or 2 to return to the menu (Note: Hard copy requires that the appropriations be 1 isted):

Typing " 2 " returns the user to the analysis menu. Typing " 1 " results in the listing of all water appropriations in the target area. A hypothetical example of the listing displayed, as well as an explanation of the information listed, is provided in the preceding "Surface Water" section. The total-appropriations listing also includes a column that indicates whether each appropriation is diverting from a surface- or ground-water source (indicated by an " $S$ " or " $G$," respectively). If a hard copy of the listing is desired, the appropriations must be listed. The appropriations that are listed are written to a file (in the user's workspace) that is available for hard-copy generation.

Following the list of total appropriations, WIMAS displays a message that provides the user the name of the newly created file. An example of the message displayed in a "User-Defined Circle" analysis is the following: 
Table 4. Basin names and associated codes of the Kansas State Board of Agriculture, Division of Water Resources

\begin{tabular}{|c|c|}
\hline Basin name & Basin code \\
\hline Arikaree River & 32 \\
\hline Arkansas River & 33 \\
\hline Bear Creek & 45 \\
\hline Beaver Creek & 30 \\
\hline Big Blue River & 13 \\
\hline Big Creek & 19 \\
\hline Black Vermillion River & 14 \\
\hline Bluff Creek (Chikaskia) & 49 \\
\hline Bluff Creek (Cimarron) & 42 \\
\hline Buckner Creek & 60 \\
\hline Caney River & 38 \\
\hline Chikaskia River & 48 \\
\hline Cimarron River & 41 \\
\hline Cottonwood River & 36 \\
\hline Cow Creek & 56 \\
\hline Crooked Creek & 43 \\
\hline Delaware River & 11 \\
\hline Driftwood Creek & 62 \\
\hline Elk River & 39 \\
\hline Fall River & 40 \\
\hline Hackberry Creek & 20 \\
\hline Kansas River & 8 \\
\hline Ladder Creek & 21 \\
\hline Little Arkansas River & 55 \\
\hline Little Blue River & 15 \\
\hline Little Osage River & 6 \\
\hline Marais Des Cygnes River & 3 \\
\hline Marmaton River & 7 \\
\hline Medicine Lodge River & 47 \\
\hline Mill Creek & 16 \\
\hline Missouri River & 1 \\
\hline North Fork Cimarron River & 44 \\
\hline North Fork Ninnescah River & 53 \\
\hline North Fork Smoky Hill River & 22 \\
\hline North Fork Solomon River & 26 \\
\hline Nemaha River & 2 \\
\hline Neosho River & 34 \\
\hline Ninnescah River & 52 \\
\hline Pawnee River & 59 \\
\hline Pottawatomie Creek & 5 \\
\hline Prairie Dog Creek & 28 \\
\hline
\end{tabular}


Table 4. Basin names and associated codes of the Kansas State Board of Agriculture, Division of Water Resources--Continued

\begin{tabular}{lc}
\hline \multicolumn{1}{c}{ Basin name } & Basin code \\
\hline Rattlesnake Creek & 57 \\
Republican River & 27 \\
South Fork Ninnescah River & 54 \\
South Fork Republican River & 31 \\
South Fork Solomon River & 25 \\
Saline River & 18 \\
Salt Creek & 24 \\
Salt Fork Arkansas River & 46 \\
Sandy Creek & 50 \\
Sappa Creek & 29 \\
Smoky Hill River & 17 \\
Solomon River & 23 \\
Spring River & 35 \\
Stranger Creek & 9 \\
Sugar Creek & 4 \\
Verdigris River & 37 \\
Vermillion Creek & 12 \\
Wakarusa River & 10 \\
Walnut Creek & 58 \\
Walnut River & 51 \\
Whitewoman Creek & 61 \\
\hline
\end{tabular}

A file for hard-copy generation, entitled circle.twa, has been created in your workspace. The file contains the above-listed appropriations.

The file name provides information about the file's contents. In this case, the prefix "circle" informs the user that the file contains information about a user-defined circle. The suffix "twa" is an abbreviation that indicates that the file contains information about total water appropriations. If the same type of analysis (for example, total appropriations) is to be performed for two or more user-defined circles, each preceding file (for example, circle.twa) that was created in the user's workspace should either be deleted or renamed prior to each subsequent analysis. Otherwise, the preceding file will be overwritten by the newly created file of the same name. This recommenda- tion applies to all options in the "User-Defined Circle" and "User-Defined Polygon" analysis menus for which files are created in the user's workspace.

Finally, a message is displayed that indicates the end of the analysis. For example, in a "UserDefined Circle" analysis, the following message is displayed:

To select another circle, click on "Quit" in the circle menu to return to the main menu.

At this point, the total-appropriations analysis is concluded, and the user is returned to the analysis menu. If desired, the user may select another analysis option to be performed on the same target area. Otherwise, the user may select the "Quit" option to return to the main menu to select another target area or exit WIMAS. 
All "User-Defined Circle" and "User-Defined Polygon" analysis options allow the user to optionally include water-use correspondent information in the listing of appropriations. Prior to the listing, the following messages are displayed:

Optionally, the name and address of the water-use correspondent may be provided as a part of the listing.

Enter 1 to include, or 2 to omit, the water-use correspondent information:

Typing "2" provides a listing similar to the hypothetical example shown in table 2. Typing "1" provides a listing similar to the hypothetical example shown in table 5. The first eight items in table 5, "FILE-ID," "OVERLAP," "TOWNSHIP," "RANGE," "SECTION," "DWR-ID," "QUALIFIERS," and "ACRE-FEET," correspond to the eight items in table 2 and have the same definitions. The next six items, "NAMEADDRESS," "ADDRESS1," "ADDRESS2," "CITY," "STATE," and "ZIPCODE" provide name and address information about the water-use correspondent. The final item, "LANDOWNER," indicates whether or not the water-use correspondent is a landowner. An asterisk indicates that the water-use correspondent is a landowner.

\section{Reported Water-Use Option}

The "Reported Water Use" option in the analysis menus provides the following submenu:
The "Reported Water Use" submenu options are described below.

\section{By-Source Suboption}

The "BY Source" suboption in the "Reported Water Use" submenu summarizes reported water use in the target area by source of water. Initially, the following prompt is displayed:

Enter either 1 (surface water) or

2 (ground water):

Typing " 1 " will initiate the surface-water-use analysis, whereas typing " 2 " will initiate the ground-water-use analysis. For example, the surface-water-use analysis would proceed as follows. If no surface-water appropriations exist within the target area, WIMAS informs the user. For example, in a "User-Defined Polygon" analysis, the following messages are displayed:

There were no surface-water appropriations in this polygon in 1991.

\section{Returning to polygon menu...}

The user is returned to the "Polygon" analysis menu.

If there are surface-water diversions in the target area, they are displayed in a unique color in the graphics window and accompanied by the following message:

Surface-water diversions are displayed in green.

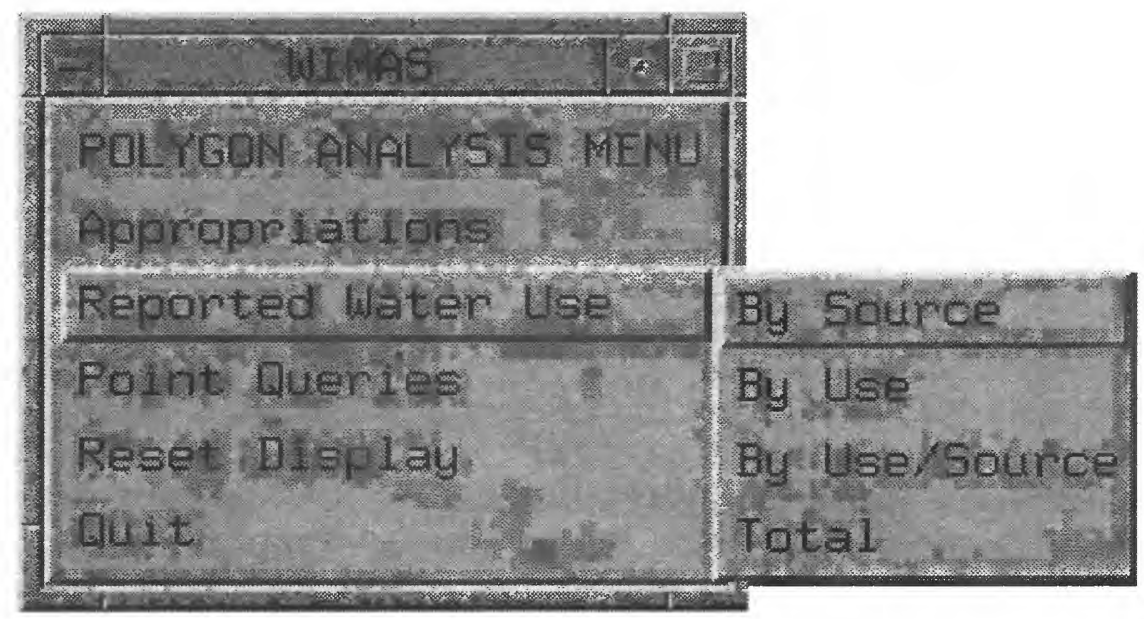


Table 5. Hypothetical example of an appropriations listing that includes water-use correspondent information

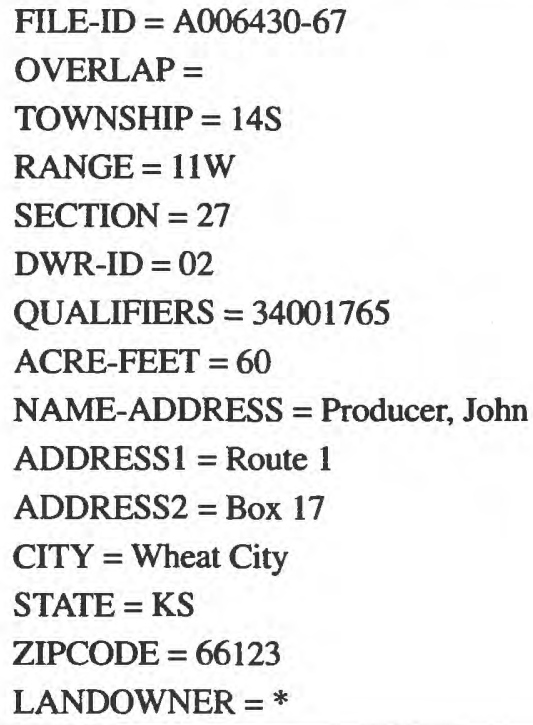

WIMAS then automatically performs the summary analysis of surface-water diversions and displays the results. A hypothetical example of the results displayed for a "User-Defined Polygon" analysis is the following:

In the polygon, 50,000,000 gallons (153 acre-feet) of surface water were reported diverted in 1991.

Water use was reported for 10 points of diversion in 1991.

The following prompt then is displayed:

Enter 1 to list the diversions or 2 to return to the menu (Note: Hard copy requires that the diversions be listed):
Typing " 2 " returns the user to the analysis menu. Typing " 1 " results in the listing of all reported surface-water diversions in the target area. A hypothetical example of the listing displayed is provided in table 6 .

The "FILE-ID" column lists the Division of Water Resources' file number (that is, the permit or water right). The "LOCATION" column provides the location of the diversion by township, range, section, and Division of Water Resources' sequential identification number, respectively. The "SOURCE" column indicates whether the diversion is from a surface- ("S") or a ground-water ("G") source. The type of water use is revealed in the "USE" column. The types of water use and associated abbreviations as categorized by the Division of Water Resources are listed in table 7.

Table 6. Hypothetical example of a surface-water-diversions listing

\begin{tabular}{cccccc}
\hline FILE-ID & LOCATION & SOURCE & USE & $\begin{array}{c}\text { GALLONS } \\
\text { USED }\end{array}$ & $\begin{array}{c}\text { ACRE-FEET } \\
\text { USED }\end{array}$ \\
\hline A002232-50 & 15 S18W2301 & S & IN & 975000 & 3 \\
A004680-72 & 16 S18W1202 & S & MU & 650000 & 2 \\
\hline
\end{tabular}


Table 7. Water-use categories and associated abbreviations of the Kansas State Board of Agriculture, Division of Water Resources

\begin{tabular}{lc}
\hline Water-use category & Water-use abbreviation \\
\hline Artificial recharge & AR \\
Contamination remediation & CR \\
Domestic & DM \\
Hydraulic dredging & HD \\
Industrial & IN \\
Irrigation & IR \\
Municipal & MU \\
Recreation & RE \\
Stockwatering & ST \\
Water power & WP \\
\hline
\end{tabular}

Finally, the "GALLONS USED" and "ACREFEET USED" columns provide the reported water use in gallons and acre-feet, respectively. If a hard copy of the listing is desired, the diversions must be listed. The surface-water diversions that are listed are written to a file (in the user's workspace) that is available for hard-copy generation.

Following the list of surface-water diversions, WIMAS displays a message that provides the user the name of the newly created file. An example of the message displayed in a "UserDefined Polygon" analysis is the following:

A file for hard-copy generation, entitled poly.swu, has been created in your workspace. The file contains the above list of reported surface-water diversions.

The file name provides information about the file's contents. In this case, the prefix "poly" informs the user that the file contains information about a userdefined polygon. The suffix "swu" is an abbreviation that indicates that the file contains information about reported surface-water use.

Finally, a message is displayed that indicates the end of the analysis. For example, in a "UserDefined Polygon" analysis, the following message is displayed:
To select another polygon, click on "Quit" in the polygon menu to return to the main menu.

At this point, the surface-water-use analysis is concluded, and the user is returned to the analysis menu. If desired, the user may select another analysis option to be performed on the same target area. Otherwise, the user may select the "Quit" option to return to the main menu to select another target area or exit WIMAS.

The ground-water-use analysis option proceeds in a like manner. The only differences are that the ground-water diversions are displayed in purple and the file created for hard copy ends in the suffix "gwu."

\section{By-Use Suboption}

The "BY Use" suboption in the "Reported Water Use" submenu summarizes reported water use in the target area by type of use. The type of use is selected from another menu, as indicated by the following prompt:

Select type of use from the menu: 
The menu invoked is shown below.

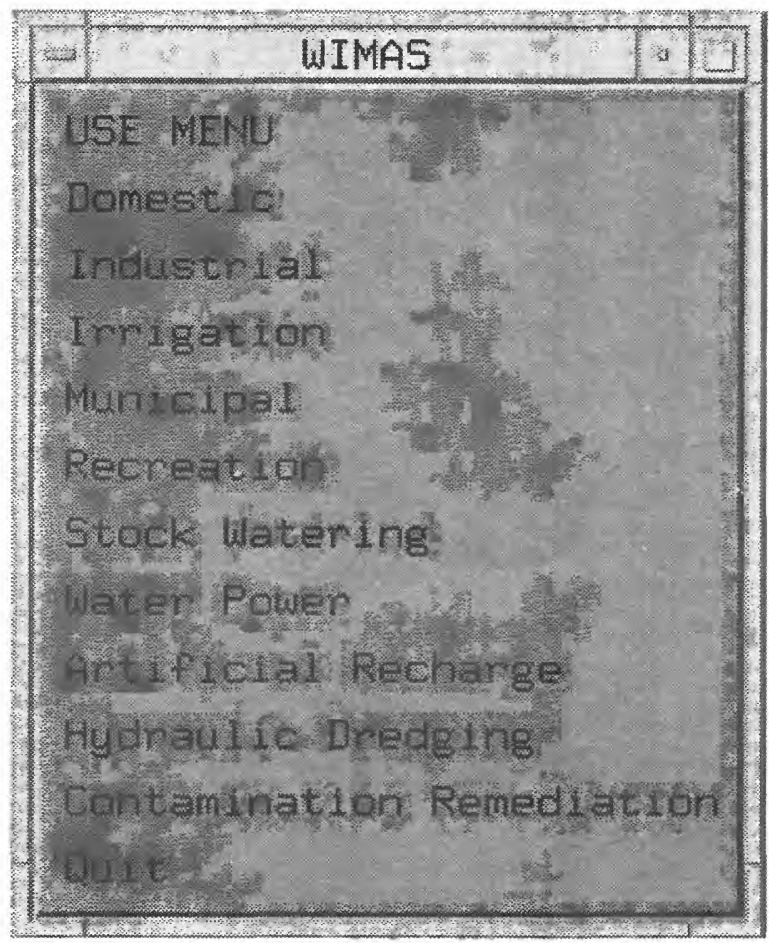

Once the type of use is selected, WIMAS automatically begins the summary analysis. (Note: The use menu will disappear until the analysis is complete.) If no appropriations exist in the target area for the selected type of use, WIMAS informs the user. Examples of the messages displayed in a "County" analysis are as follows:

There was no industrial water use reported in the county for 1991.

Returning to use menu...

The user is returned to the use menu.

If there are diversions for the selected type of use in the target area, they are displayed in a unique color in the graphics window and accompanied by a message similar to the following:

Diversions for industrial water use are displayed in red.

WIMAS then completes the summary analysis of diversions for the selected type of use and displays the results. A hypothetical example of the results displayed for a "County" analysis is the following:
In Mitchell County, 10,000,000 gallons (31 acre-feet) of water were reported diverted for industrial purposes in 1991.

Water use for industrial purposes was reported for 2 points of diversion in 1991.

The following prompt then is displayed:

Enter 1 to list the diversions or 2 to return to the menu (Note: Hard copy requires that the diversions be listed):

Typing "2" returns the user to the use menu. Typing " 1 " results in the listing of all reported diversions for the selected type of use in the target area. A hypothetical example of the listing displayed, as well as an explanation of the information listed, is provided in the preceding "By Source" section. If a hard copy of the listing is desired, the diversions must be listed. The diversions that are listed are written to a file (in the user's workspace) that is available for hard-copy generation.

Following the list of diversions, WIMAS displays a message that provides the user the name of the newly created file. An example of the message displayed in a "County" analysis is the following:

A file for hard-copy generation, entitled mitchell.inwu, has been created in your workspace. The file contains the above list of reported diversions.

The file name provides information about the file's contents. In this case, the prefix "mitchell" informs the user that the file contains information about Mitchell County, Kansas. The suffix "inwu" is an abbreviation that indicates that the file contains information about industrial water use.

Finally, a message is displayed that indicates the end of the analysis. For example, in a "County" analysis the following message is displayed:

Select another use or select "Quit" to return to the county menu. 
At this point, the type-of-use analysis is concluded, and the user is returned to the use menu. If desired, the user may select another type-of-use analysis option to be performed on the same target area. Otherwise, the user may select the "Quit" option to return to the analysis menu to select other analysis options that are available for the same target area. To select a new target area or exit WIMAS, the user must select the "Quit" option in the analysis menu to return to the main menu.

\section{By-Use/Source Suboption}

The "By Use/Source" suboption in the "Reported Water Use" submenu summarizes reported water use in a target area by type of use and source of water. The use/source is selected from another menu, as indicated by the following prompt:

Select type of use and source from the menu:

The menu invoked is shown below.

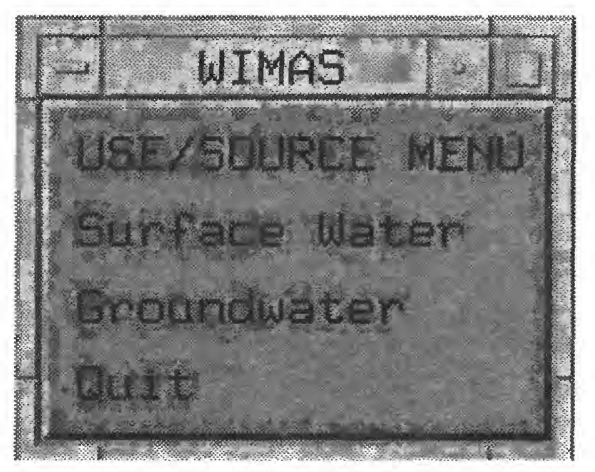

A use/source choice is made by first selecting either the "Surface Water" or "Groundwater" option. Subsequently, a submenu is displayed that provides the type-of-use options (see table 7) with which the user may then complete the selection.

Once the use/source is selected, WIMAS automatically begins the summary analysis. (Note: The use/source menu will disappear until the analysis is complete.) If no appropriations exist in the target area for the selected use/source, WIMAS informs the user. Examples of the messages displayed in a "Basin" analysis are as follows:
There was no municipal surfacewater use reported in the basin for 1991.

Returning to the use/source menu...

The user is returned to the use/source menu.

If there are diversions for the selected use/ source in the target area, they are displayed in a unique color/symbol combination in the graphics window and accompanied by a message like the following:

Diversions for municipal surfacewater use are displayed as open blue circles.

WIMAS then completes the summary analysis of diversions for the selected type of use and source of water and displays the results. A hypothetical example of the results displayed for a "Basin" analysis is the following:

In the Wakarusa River Basin, $60,000,000$ gallons (184 acre-feet) of water were reported diverted for municipal surface-water use purposes in 1991.

Water use for municipal surfacewater use purposes was reported for 5 points of diversion in 1991.

The following prompt then is displayed:

Enter 1 to list the diversions or

2 to return to the menu (Note:

Hard copy requires that the diversions be listed):

Typing " 2 " returns the user to the use/source menu. Typing "l" results in the listing of all reported diversions for the selected use/source in the target area. A hypothetical example of the listing displayed, as well as an explanation of the information listed, is provided in the preceding "By Source" section. If a hard copy of the listing is desired, the diversions must be listed. The diversions that are listed are written to a file (in the user's workspace) that is available for hard-copy generation.

Following the list of diversions, WIMAS displays a message that provides the user the name of the newly created file. An example of the 
message displayed in a "Bas in" analysis is the following:

A file for hard-copy generation, entitled basin10.mswu, has been created in your workspace. The file contains the above list of reported diversions.

The file name provides information about the file's contents. In this case, the prefix "basin 10" informs the user that the file contains information about a specific basin (in this case, the Wakarusa River Basin in Kansas). The suffix "mswu" is an abbreviation that indicates that the file contains information about municipal surface-water use.

Finally, a message is displayed that indicates the end of the analysis. For example, in a "Bas in" analysis, the following message is displayed:

Select another use/source or select "Quit" to return to the basin menu.

At this point, the use/source analysis is concluded, and the user is returned to the use/source menu. If desired, the user may select another use/source analysis option to be performed on the same target area. Otherwise, the user may select the "Quit" option to return to the analysis menu to select other analysis options that are available for the same target area. To select a new target area or exit WIMAS, the user must select the "Quit" option in the analysis menu to return to the main menu.

\section{Total Suboption}

The "Total" suboption in the "Reported Water Use" submenu collectively summarizes all reported water use in the target area. If no appropriations exist in the target area, WIMAS informs the user. Examples of the messages displayed in a "User-Defined Circle" analysis are as follows:

There were no appropriations in this circle in 1991.

Returning to circle menu...

The user is returned to the "CirCle" analysis menu.

If there are diversions in the target area, WIMAS automatically performs the summary analysis of total water use and displays the results. A hypothetical example of the results displayed for a "User-Defined Circle" analysis is the following:

In the circle, $18,000,000$ gallons

(55 acre-feet) of water were

reported diverted in 1991.

Water use was reported for

2 points of diversion in 1991.

The following prompt then is displayed:

Enter 1 to list the diversions or

2 to return to the menu (Note:

Hard copy requires that the diversions be listed):

Typing " 2 " returns the user to the analysis menu. Typing "l" results in the listing of all reported diversions in the target area. A hypothetical example of the listing displayed, as well as an explanation of the information listed, is provided in the preceding "BY Source" section. If a hard copy of the listing is desired, the diversions must be listed. The diversions that are listed are written to a file (in the user's workspace) that is available for hard-copy generation.

Following the list of diversions, WIMAS displays a message that provides the user the name of the newly created file. An example of the message displayed in a "User-Defined Circle" analysis is the following:

A file for hard-copy generation, entitled circle.twu, has been created in your workspace. The file contains the above list of reported diversions.

The file name provides information about the file's contents. In this case, the prefix "circle" informs the user that the file contains information about a user-defined circle. The suffix "twu" indicates that the file contains information about total water use.

At this point, the total water-use analysis is concluded, and the user is returned to the analysis menu. If desired, the user may select another analysis option to be performed on the same target area. Otherwise, the user may select the "Quit" option to return to the main menu to select a new target area or exit WIMAS. 
All "User-Defined Circle" and "User-Defined Polygon" analysis options allow the user to optionally include water-use correspondent information in the listing of diversions. Prior to the listing, the following messages are displayed:

Optionally, the name and address of the water-use correspondent may be provided as a part of the listing.

Enter 1 to include, or 2 to omit, the water-use correspondent information:

Typing " 2 " provides a listing similar to the hypothetical example shown in table 6. Typing " 1 " provides a listing similar to the hypothetical example shown in table 8 . The first six items in table 8, "FILE-ID," "LOCATION," "SOURCE," "USE," "GALLONS USED," and "ACRE-FEET USED," correspond to the six items in table 6 and have the same definitions. The next six items, "NAME-ADDRESS," "ADDRESS1," "ADDRESS2," "CITY," "STATE," and "ZIPCODE" provide name and address information about the water-use correspondent. The final item, "LANDOWNER," indicates whether or not the water-use correspondent is a landowner. An asterisk indicates that the water-use correspondent is a landowner.

\section{Point-Queries Option}

The "Point Queries" option in the analysis menu provides the capability to interactively select one or many points of diversion in a target area.

Initially, the following prompt is displayed:

Enter the desired search radius (in feet):

At this point, the user enters the search radius. (Note: The radius may be given as either an integer or a decimal number.) The size of the search radius required to find the target point of diversion is related directly to the size of the target area that contains the point of diversion. For example, in a user-defined circle (of radius 5 miles or less) a search radius of 50 feet or less may be sufficient, whereas in a county or basin a search radius of 500 feet or more may be required.

The following prompt is then displayed:

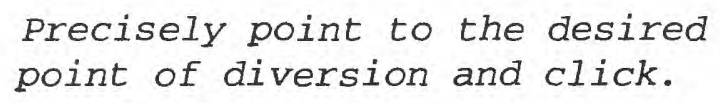

When the above message appears, the user moves the cursor into the graphics window and waits for the cross hairs to align with the cursor. Subsequently, the user may make a selection by pointing to and clicking on the desired point of diversion. (Note: Only one point of diversion can be selected at a time.)

Table 8. Hypothetical example of a diversions listing that includes water-use correspondent information

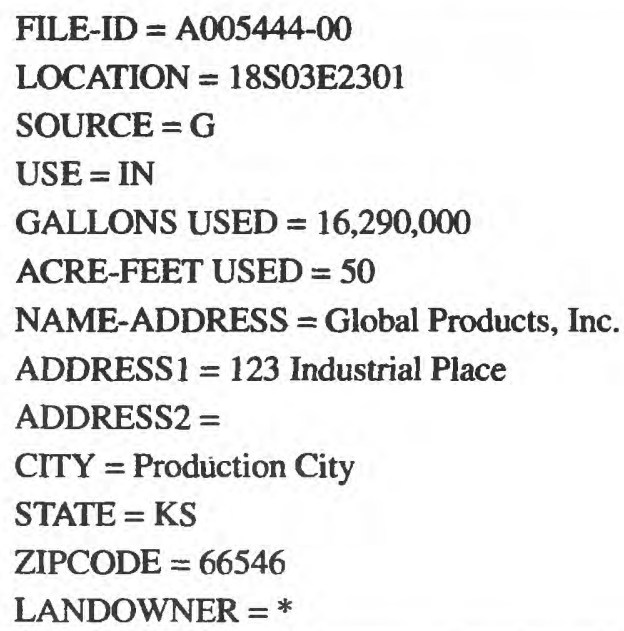


WIMAS performs a spatial search and reports how many appropriations were located. If no appropriations were found, WIMAS informs the user with the following message:

No point was selected...

In this case, the user may want to try again using a larger search radius.

If appropriations were found, WIMAS informs the user with a message similar to the following (Note: A single point of diversion may have one or many appropriations associated with it.):

2 file-id(s) selected...

For each appropriation, information (as described earlier) is listed that includes the Division of Water Resources' file number, overlap indicator, locational information, source of water, type of use, appropriated annual quantity, reported annual use, name and address of the water-use correspondent, and the landowner indicator. The listing provided is a combination of the examples given in tables 5 and 8.

Following the listing, the user is prompted to select another point or quit. For example, in a "User-Defined Polygon" analysis, the following message is displayed:

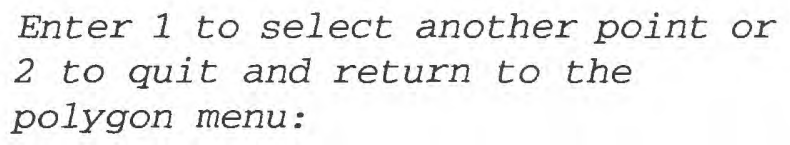

Typing "1" enables the user to select another point of diversion, whereas typing " 2 " returns the user to the "Polygon" analysis menu.

\section{Reset-Display Option}

The "Reset Display" option in the analysis menu clears the current graphics display and redisplays the original target area. This option is useful in situations where the user desires multiple analyses for the same target area and wants to avoid a graphics display that becomes difficult to interpret due to the overlay of multiple color and symbol combinations. This option is also necessary to renew the display following any modifications to the size and shape of the graphics window that the user may make during a session. Once the display is reset, the user is returned to the analysis menu.

\section{SYSTEM AVAILABILITY}

The WIMAS software, as well as all digital maps and data files used by the system, are available in digital form from the U.S. Geological Survey (Lawrence, Kansas) and the Kansas State GIS Data Access and Support Center (Lawrence, Kansas).

\section{SUMMARY}

To improve accessibility to and enhance the use of the Kansas State Board of Agriculture, Division of Water Resources' water-appropriations and water-use data bases, geographic-informationsystem (GIS) technology was used to develop a user-support tool referred to as the Water Information Management and Analysis System (WIMAS). WIMAS enables users to summarize, in graphic and tabular form, water-appropriations and wateruse information by geographic area (that is, county, basin, user-defined polygon, user-defined circle), source of water, and type of water use.

\section{REFERENCE}

Environmental Systems Research Institute, Inc., 1992, ARC/INFO geographic-information-system software: Redlands, Calif., Environmental Systems Research Institute, Inc., various pagination. 